\title{
PENAL MEDIATION AS ALTERNATIVE DISPUTE RESOLUTION IN PAREPARE
}

\author{
Andi Marlina \\ Islamic Criminal Law Study Program, Faculty of Sharia and Islamic Law \\ Institut Agama Islam Negeri (IAIN) Parepare \\ Email: andi.marlina.iainpare2@gmail.com
}

\begin{abstract}
The purpose of this study is to analyze the penal mediation that does not aim to achieve formal justice and the practice of penal mediation at the Parepare Police Department. The research method is normative legal research, using a statute and conceptual approach. The collected legal materials are then analyzed qualitatively, then presented descriptively. The results showed that the dimension of mediation of the penalties achieved was not formal justice through the Criminal Justice sub-system regulated in formal legal regulations. From a juridical perspective, mediation of penalties in the dimensions of state law (ius constitutum) is actually not well known and still leaves controversy among those who agree and disagree to be applied. The essential issue leads to the choice of a pattern of criminal dispute resolution, related to the domain of state superiority with the superiority of the local wisdom community. The practice of mediating penalties at the Parepare Police Department in the last 3 years (2017, 2018 and 2019) the number of criminal cases every year has always increased in number, as well as the mediation of cases conducted by the Manokwari Police Department each year experiencing an increase in the number of criminal cases being mediated.
\end{abstract}

Keywords: Penal Mediation, Criminal Cases, Restorative Justice.

\section{A. INTRODUCTION}

The logical consequence of the development of criminal law is the growth of the private nature of criminal law. As time and society progress, criminal law has been directed, grew, and developed into public law. The existence of criminal law as a part of public law, gradually, is to protect the public and state interest by harmoniously balancing between crimes and arbitrary state acts.

The complex changes and dynamics of society and the partial legislation process shifted the nature of public law. It was possible due to its relative tendency towards a more private and personal domain, and the practice of penal mediation as an alternative dispute resolution outside the court. ${ }^{1}$

${ }^{1}$ Puslitbang Hukum dan Peradilan Badan Litbang Diklat Kumdil Mahkamah Agung RI, 2011, Mediasi Penal Dalam Sistem Peradilan Pidana, Jakarta, 2011, p.10 
Penal mediation is one of the alternative dispute resolutions outside the court (ADR) and is commonly practiced in civil cases. In this dimension, ADR outside the court has been regulated under the Act No.30/1999 on Arbitration and Alternative Dispute Resolution. Several institutions have been continuously promoting the ADR method. Among them is BANI Arbitration Centre (BANI), which focused on trade and $A D R$ in resolving construction services disputes (Act No. 18/1999, Act No. 29/2000, PP No. 29/2000) with jurisdiction in civil cases. Similarly, ADR is commonly found in cases such as regarding copyrights and intellectual works, labors, business competition, consumer protection, and the environment. ${ }^{2}$

The principles of criminal cases in Indonesian's positive law cannot be resolved outside the court despite the possibility of doing so outside the court. Practically, law enforcement, as well as criminal cases, was often resolved outside the court through discretion, peace mechanism, and customary institutions. The implications of dispute resolution outside the court practices have not yet to be formally regulated. Therefore, it is common to have disputes resolved in customary laws but are still processed in the court, in compliance with the prevailing positive law. The consequence of penal mediation as an alternative criminal case resolution indicates small differences between criminal and civil cases, which do not function properly. ${ }^{3}$

The existence of dispute resolution outside the court through penal mediation is a new dimension in theoretical and practical researches. Penal mediation, from practical dimension lens, correlates with the judicature achievement. The increase of reported cases in court has become a burden for the court to assess and decide disputes under the principle of "a simple, quick, and inexpensive judicial process" without forfeiting the judicature objectives, i.e., legal certainty, expediency, and justice.

$2 \quad$ Ibid, p.17.

3 Barda Nawawi Arief, Mediasi Penal Penyelesaian Perkara Diluar Pengadilan, Pustaka Magister, Semarang, 2008, pp. 4-5. 
Penal mediation gained its momentum with the Letter of National Police Chief No. Pol: B/3022/XII/2009/SDEOPS, dated 14 ${ }^{\text {th }}$ December 2009 on Case Resolution through Alternative Dispute Resolution (ADR) that emphasizes criminal case resolution through ADR by the agreement of the disputed parties. However, the letter is strictly internal and does not publicly applicable. Thus, legally, penal mediation in Indonesia has not yet to be strongly regulated.

Indonesian Police then issued the Circular Letter of National Police Chief No: SE/8/VII/2018 on the Implementation of Restorative Justice in Criminal Case Resolution. Fundamentally, it regulates criminal case resolution through the restorative justice approach with the fulfillment of material and formal requirements. Material requirements demand the dispute to avoid public unrest and rejection, avoid social conflict, be without objections from the involved parties, and the involved parties to abandon their rights to sue. Similarly, formal requirements demand, among all, the letter of settlement of both parties. The letter of settlement (Acte van Dading) and the dispute resolution of the involved parties must be made known to the senior investigator.

Police Department is a frontline institution in the law enforcement process with the authority to conduct preliminary investigation and investigation as regulated in the Criminal Law Procedures Code (KUHAP). ${ }^{4}$ The preliminary investigation and investigation of a criminal case is an entry point of criminal law enforcement through the criminal justice system in Indonesia. Therefore, the preliminary investigation and investigation of a criminal case is essential in determining whether a case can be processed to the prosecution and judicial process to achieve the judicature objectives, i.e., legal certainty and expediency by emphasizing on the principle of simple, quick, and inexpensive judicial process.

Considering the development of the law enforcement system and method in Indonesia tend to follow the development of public justice, mainly the

\section{Pidana Indonesia.}

Pasal 1 angka 1 dan Pasal 1 angka 4 Kitab Undang-undang Hukum Acara 
development of restorative justice principles. The principles reflect justice as harmony, and thus, crimes are regarded as acts that disrupt the harmony. Therefore, the dispute resolution method used is an effort to restore the harmony, by requiring the offenders to acknowledge the crime and repairing the harms caused by the crime to the victim to fulfill the victim's sense of justice.

These are the guidelines for the Police Department, including Parepare Police Department, to handle criminal cases in their jurisdiction area. Based on the temporary data from the last three years (2017-2019), the number of criminal cases handled by Parepare Police Department is 742 cases. Based on the Circular Letter of National Police Chief No: SE/8/VII/2018 on the Implementation of Restorative Justice in Criminal Case Resolution, the number of criminal cases that have been resolved by Polresta Parepare through penal mediation is 158 cases in the last three years. 


\section{B. METHOD}

a. Research Method and Location

The method of research employed was socio-legal research, which is legal research that obtains the data from the primary data source. Therefore to obtain the data related to criminal cases and penal mediation, the research was conducted in Parepare Police Department, Kota Parepare, Sulawesi Selatan.

\section{b. Data Types and Source}

The obtained and analyzed data in socio-legal research were primary and secondary data. The primary data or raw data were obtained through interviews and were further analyzed. Interviews were conducted by formulating a list of questions that were asked to competent interviewees. The collected legal materials were carefully selected to obtain the appropriate, desired data.

\section{c. Data Analysis}

The collected legal materials were further analyzed using descriptive qualitative method. Primary and secondary legal materials that have been collected and formulated based on the research topic were classified based on their source and hierarchy. These materials, then, were further explained according to the research findings.

\section{FINDINGS AND DISCUSSION}

1) Legal Position of Penal Mediation in Criminal Justice System in Indonesia

Dispute resolution outside the court through penal mediation is a new development in criminal law that brought private dimension into public law. In penal mediation, formal justice is not achieved through the criminal justice subsystem as regulated under legal, formal regulation. In penal mediation, the highest justice is achieved because of the agreement between the involved parties, i.e., the victim and the offender. Both parties are hoped to seek and obtain the best alternative solution to resolve the dispute. This achievement 
implies that both the victim and the offender could offer compensation that would be negotiated and agreed by both parties to achieve a "win-win" solution.

Penal mediation, in its essence, is developed from the following ideas and working principles: ${ }^{5}$

a. Conflict Handling:

Mediators advised the involved parties to ignore the legal framework and invite them to the communication process. This is based on the idea that the crime has created an interpersonal conflict and that the mediation process will address conflict.

b. Process Oriented:

Mediation is more oriented towards the quality rather than the result. The main aims are to make the offender aware of its crime, to resolve the conflict needs, and to keep the victim from fear.

c. Informal Proceeding:

Penal mediation is an informal, non-bureaucratic proceeding that avoids the strict legal proceeding.

d. Active and Autonomous Participation of the Involved Parties:

Both offender and victim are seen not as the objects of criminal law procedures but instead as subjects with personal responsibility and ability to act. Both parties are expected to act on their own will.

Dispute resolution outside the court through penal mediation is regulated partially and limited with its gradation is regulated under the Constitution. However, in its regulation limit under the Constitution, criminal cases cannot be resolved outside the court despite in certain circumstances, it is possible to do so. However, it is outside the boundary of penal mediation.

Moreover, in the context of Criminal Justice System (SPP), specifically in its sub-system, penal mediation is proved to be practiced effectively by the

5 Barda Nawawi Arief, Mediasi Penal Penyelesaian, Ibid,5-6. 
Police Department compared to Public Prosecutor or the Court, as stated by Adrianus Meliala: ${ }^{6}$

ADR is essential to be practiced by the Police Department compared to Public Prosecutor or Court considering the role of the Police Department as the initial point of the Criminal Justice System.

From the restorative perspective, justice is not only traced from the victim-centered point of view, but rather, the offender's point of view is also traced to have the offender acknowledge and be responsible for the crimes committed to the victim and society. ${ }^{7}$ Several criminal cases in Indonesia have been resolved through mediation, especially those that involved juveniles. In Act No. 11/2012 on the Criminal Justice System of Juvenile, it is regulated to resolve criminal cases through diversion. Despite using a different term, this is one form of penal mediation with restorative justice as its essence. Moreover, Article 7, Paragraph (1) of a quo law demands the pursue of diversion at the level of investigation, prosecution and court proceedings of juvenile cases in District Court, restricted only to criminal cases punishable by imprisonment under 7 (seven) years and is not a repetition of criminal acts (recidivist).

In addition, domestic violence as regulated in Articles 51-53 of Act No. 23/2004 on the Elimination of Domestic Violence that physical, psychological, and sexual violence are categorized as offense complaint. Therefore, to ensure the cordiality and the integrality of a household, domestic violence is often resolved through mediation.

Other criminal cases that could be resolved through mediation are criminalization in copyrights cases as regulated in Article 95, Paragraph (4) of Act No. 28/2014 on Copyrights, and criminalization in Patents as regulated in Article 154 of Act No. 13/2016 on Patents.

Practically, penal mediation has been implemented by the Police Department, including Parepare Police Department. It is based on the Circular

$6 \quad$ Adrianus Meliala, Penyelesaian Sengketa Alternatif: Posisi dan Potensinya di Indonesia, Makalah, pp.8-9.

${ }^{7}$ https://www.hukumonline.com/berita/baca/lt5be1858164328/ini-kasus-kasus-pidanayang-bisa-dimediasi-di-indonesia/, accessed $23^{\text {rd }}$ February 2020, 09.38 WITA. 
Letter of National Police Chief No: SE/8/VII/2018 on the Implementation of Restorative Justice in Criminal Case Resolution. Fundamentally, the regulation regulates criminal case resolution through the restorative justice approach with the fulfillment of material and formal requirements.

It is based on the development of law enforcement concept in several countries that have adopted restorative justice in addition to problems that have emerged in the criminal law enforcement process. These problems are including the high number of inmates in penitentiary institutions and case arrears, the unequal ratio between law enforcers and cases, and high spending of several cases. These problems brought changes to the legal culture, especially on the perspective of society in the criminal law enforcement process.

Moreover, to fulfill the needs of law and justice, the Indonesian Police Department, as the institution that has been given authority to investigate, coordinate, and supervise criminal case investigation, has formulated new concepts in criminal law enforcement. These new concepts are primarily during the preliminary investigation and investigation process that could accommodate society's justice values and provide legal certainty, especially procedural certainty.

Based on the Circular Letter of National Police Chief No: SE/8/VII/2018 on the Implementation of Restorative Justice in Criminal Case Resolution, criminal case resolution methods that reflect the practice of restorative justice can be used as guidelines in implementing restorative justice on criminal cases, as follows: 8

1) Article 76, Paragraph (1) of KUHP stated that except for the cases where judicial verdicts are subject to revision, no person should be

8 Surat Edaran Kapolri No : SE/8/VII/2018 tentang Penerapan Keadilan Restoratif (Restorative Justice) Dalam Penyelesaian Perkara Pidana. 
prosecuted again by reason of an act, which the verdict of an Indonesian judge with respect to him has become final;

2) Article 7, Paragraph (1) of Act No. 11/2012 on Criminal Justice System of Children stated that at the level of investigation, prosecution and court proceedings of juvenile cases in District Court must be pursued diversion;

3) Article 15, Paragraph (2) of Act No. 42/1999 on Fiduciary stated that Fiduciary Certificate has the same power as enforceable court decisions that have permanent legal force.

4) Article 51, Paragraph (7) of Act No. 21/2001 on Special Autonomy for the Papua Province stated that in order to release the criminal offender from criminal charges according to prevailing criminal laws, a statement of approval is required from the Chairman of the District Court obtained through the Head of the District Prosecutors Office concerned with the scene of the crime.

The authority of police investigators that implement restorative justice principle as the investigation method is regulated, as follows: ${ }^{9}$

1) Article 7, Paragraph (1), Letter $J$ of Act No. 8/1981 on Criminal Procedure Law stated that an investigator has the authority to take another responsible legal measure;

2) Article 16, Paragraph (1), Letter $L$ and Article 18 of Act No. 2/2002 on State Police of the Republic of Indonesia and Article 5, Paragraph (1), Section 4 of Act No. 8/1981 on Criminal Procedure Law stated that other responsible legal measures as mentioned in Article 16, Paragraph (1), Letter $L$ is preliminary investigation and investigation conducted under the following requirements:

a. shall not be contrary to the rule of law;

b. shall be parallel with legal obligations that must be conducted;

9 Surat Edaran Kapolri No : SE/8/VII/2018 tentang Penerapan Keadilan Restoratif (Restorative Justice) Dalam Penyelesaian Perkara Pidana. 
c. shall be proper, reasonable and under their jurisdiction;

d. shall be based on proper consideration and urgency; and

e. shall respect human rights.

3) Article 18 of Act No. 2/2002 on State Police of the Republic of Indonesia stated that for general interests, officials of the State Police of the Republic of Indonesia might act based on their consideration in implementing tasks and authorities. Article 18, Paragraph (2) of Act No. 2/2002 on State Police of the Republic of Indonesia stated that the implementation of the provisions referred to in Paragraph (1) might only be conducted if necessary by considering existing laws and regulation and the Profession Ethical Code of the State Police of the Republic of Indonesia;

4) Article 22, Paragraph (2), Letter B and C of Act No. 30/2014 on Government Administration stated that every discretion made by government officials is intended to fill the legal vacuum and to provide legal certainty.

The restorative approach used, especially by the Police Department, in resolving criminal cases, is based on the following handling guidelines: ${ }^{10}$

a. Material requirements fulfilled, which are:

1) Shall not create public unrest and objection;

2) Shall not create social conflict;

3) Shall not be objected by the involved parties, and the involved parties shall abandon their rights to sue before the law;

4) Shall meet the limitation principles:

a) On offender:

1. The offender's guilt is not relatively severe, that is negligent (Schuld or mans rea) in the form of intention (dolus or opzet) mainly intention as an objective (opzet als oogmerk);

10 Surat Edaran Kapolri No : SE/8/VII/2018 tentang Penerapan Keadilan Restoratif (Restorative Justice) Dalam Penyelesaian Perkara Pidana. 
2. The offender is not a recidivist;

b) On the criminal act in the proceeding:

1. Preliminary investigation;

2. Investigation before the admission of SPDP to the Public Prosecutor;

b. Formal requirements fulfilled, which are:

1) Application for Settlement of both parties;

2) Letter of Settlement (Acte van Dading) and the dispute settlement of the involved parties must be made known to the senior police investigator;

3) Notice of Additional Inspection of the involved parties has been completed through restorative justice;

4) Recommendation of Special Case Reconstruction that approved restorative justice;

5) The offender has no objection to the responsibility and indemnities which are done voluntarily.

6) Restorative justice can be implemented on all general criminal cases with no human casualties;

The practice of penal mediation by the Police Department, especially police investigators, is an effort to apply or implement restorative justice. The effort is intended for the benefit of society. A criminal sanction is not necessary, otherwise bringing justice to the victim and bringing the offender to realize its crime is the best solution to restore harmony in society.

The implementation of restorative justice through penal mediation by police investigators is following the progressive law stated by Satjopto Raharjo that the law is for humankind, not humankind is for the law. ${ }^{11}$ Police investigators should put law as a means to achieve the objectives of

11 Satjipto Rahardjo.2007, Membangun Polisi sipil, Perspektif Hukum, Sosial, dan Kemasyarakatan, Jakarta: PT Kompas Media Nusantara. 
humankind, individually or collectively as a group or society, rather than discord it with the existing legal procedures and forfeit humankind's objectives.

\section{2) The Effectiveness of the Practice of Penal Mediation in Dispute Resolution in Parepare Police Department}

In the last three years (2017-2019), the number of criminal cases resolved by Parepare Police Department is 742 cases, and approximately 158 cases were resolved through penal mediation, as can be seen in the following table: ${ }^{12}$

Table 1. Cases and Penal Mediation in 2017-2019

\begin{tabular}{|c|c|c|}
\hline Year & Cases & Mediation \\
\hline 2017 & 158 & 28 \\
\hline 2018 & 272 & 57 \\
\hline 2019 & 312 & 73 \\
\hline Jumlah & 742 & 158 \\
\hline
\end{tabular}

Source : Polresta Parepare

It can be derived from the table above that in the last three years, the number of criminal cases handled and the number of cases resolved through mediation has continuously been increasing. Based on that, it can be concluded that criminal cases that have been resolved through mediation are the implementation of the Circular Letter of National Police Chief No: SE/8/VII/2018 on the Implementation of Restorative Justice in Criminal Case Resolution.

In the circular letter, it has been notified and decreed to resolve disputes through restorative justice approach to avoid dissimilarities of investigation administration, dissimilarities in interpretations, and any misappropriations in implementation. The circular letter has regulated the guidelines in handling criminal cases with its material and formal requirements. Moreover, the implementation mechanism of restorative justice is described as follows:

12 Data Kasus Pidana Polresta Parepare, tahun 2020. 
1) After the admission of application of settlement from all involved parties which has been signed on stamped paper, verify the formal requirements for the dispute resolution through restorative justice;

2) Following the fulfillment of the formal requirements, the application of settlement is forwarded to the senior police investigator for approval;

3) Following the approval from the senior police investigator (Kabareskrim/ Kapolda/Kapolres), the date for the signing of the letter of settlement is scheduled;

4) The conference that issued the letter of settlement, which is signed by all involved parties, is held;

5) An official memo addressed to the police investigator supervisor or Kasatker regarding the special case reconstruction to resolve the dispute is issued;

6) The special case reconstruction is held, with the presence of the complainant and/or the complainant's family, complainee and/or the complainee's family and the representative of leaders of society appointed by police investigators, representative of internal and legal supervisor and government official if necessary;

7) Administrative requirements, the special case reconstruction, and the report of the case reconstruction are prepared;

8) Cessation of Investigation Order and Cessation of Investigation Decree for the reason of restorative justice are issued;

9) For cases in the preliminary investigation phase, the police investigator issued Cessation of Investigation Order and Cessation of Investigation Decree signed by:
a) Director of Criminal Investigation in Mabes Polri;
b) Director of Criminal Investigation in Polda;
c) Chief of Departmental Police in Polres and Polsek;

10) For cases in the investigation phase, the police investigator issued Cessation of Investigation Order and Cessation of Investigation Decree enclosed with this Circular Letter and signed by:

a) Director of Criminal Investigation in Mabes Polri; 
b) Director of Criminal Investigation in Polda;

c) Chief of Departmental Police in Polres and Polsek;

11) The report of the case is recorded into the new register (B-19) as a restorative justice case and noted as case resolution.

The Circular Letter of National Police Chief No: SE/8/VII/2018 on the Implementation of Restorative Justice in Criminal Case Resolution has been guiding the case resolutions done by police investigators from Parepare Police Department. From the interview conducted on $12^{\text {th }}$ November 2019 in Parepare Police Department with Juman Simanjuntak, Head of Criminal Investigation Operational Development Affairs of Parepare Police Department, it was concluded that: ${ }^{13}$

The legal framework of the practice of mediation which is one of the alternative dispute resolution systems in Indonesia is:

1) Pancasila, as the national ideology of the Republic of Indonesia, where one of its principles is deliberation to consensus.

2) UUD 1945, as the state constitution of the Republic of Indonesia, where deliberation to consensus is embodied in its articles.

5) Article 7, Paragraph (1), Letter $J$ of Act No. 8/1981 on Criminal Procedure Law, stated that an investigator has the authority to take another responsible legal measure.

6) Article 51, Paragraph (7) of Act No. 21/2001 on Special Autonomy for the Papua Province stated that in order to release the criminal offender from criminal charges according to prevailing criminal laws, a statement of approval is required from the Chairman of the District Court obtained through the Head of the District Prosecutors Office concerned with the scene of the crime.

\section{Parepare}

${ }^{13}$ Wawancara dengan Juman Simanjuntak, tanggal 6 Januari 2020 di Kantor Polresta 
3) Article 16, Paragraph (1), Letter L of Act No. 2/2002 stated that the acts of the State Police of the Republic of Indonesia are preliminary investigation and investigation.

4) Article 18 of Act No. 2/2002 stated that for general interests, officials of the State Police of the Republic of Indonesia might act based on their consideration in implementing tasks and authorities.

5) Circular Letter of the National Police Chief No: $8 / 2018$, dated $27^{\text {th }}$ July 2018 on the Implementation of Restorative Justice in Criminal Case Resolution and the Mechanism to Implement Restorative Justice.

Based on the interview, the penal mediation practiced in criminal case resolution in Parepare Police Department is unknown in the Criminal Justice System. However, under the Constitution, it is partially known as discretion made by the law enforcer.

The penal mediation practiced by Parepare Police Department in resolving criminal cases is the implementation of restorative justice. As stated in the Circular Letter of the National Police Chief No: SE/8/VII/2018 on the Implementation of Restorative Justice in Criminal Case Resolution that one of the material requirements that need to be fulfilled is the criminal case should have a social impact on society.

Police investigators in handling criminal cases are, without a doubt, faced with choices between legal certainty and justice and expediency. Therefore, police investigators have the authority for discretion in determining which acts should be taken. The concept of discretion in relatively simple as it stated that police investigators have the authority to decide or to choose acts necessary in resolving criminal cases based on laws with regards to the situation and condition, with their consideration for general interests.

The practice of mediation, especially by police investigators, is an effort to actualize or to implement restorative justice. The practice of mediation is not only limited to light criminal cases but to general criminal cases based on several considerations, as stated in the Circular Letter of the National Police Chief No: SE/8/VII/2018 on the Implementation of Restorative Justice in 


\section{Andi Marlina}

Criminal Case Resolution. These efforts are intended for the general interests where it is not necessary to have criminal sanctions in law enforcement. Instead, upholding justice for the victim and bringing the offender to acknowledge and realize its crime is the best solution for the general interests.

Based on the information from interviewees, it is found that police investigators in Parepare Police Department took several steps in implementing restorative justice. Among them are mediations of the involved parties and efforts to restore "harms" caused by a criminal act. The efforts of restoring "harms" are accompanied by efforts to restore the relationship between the victim, the offender, and the general public. In restoring the relationship of the general public, public leaders, or government officials are involved.

The mechanism of dispute resolution through restorative justice is not only put the society as spectators to the efforts but instead involves them in supervising the outcome of the criminal case resolution. The implementation of restorative justice through penal mediation is a dispute resolution outside of the Legal System provisions. However, the practice of penal mediation is intended to uphold justice and expediency from the victim and the offender, which sometimes neglects legal certainty.

Criminal case resolution that upholds restorative justice is the embodiment of the implementation of progressive law because, essentially, the main goal is the general interests. On this matter, police investigators in Parepare Police Department have put laws based on the needs of society. Thus, the true goal of the law has been achieved.

The practice of penal mediation as an effort to implement the restorative justice principles has put police investigators to the frontline. Thus, police investigators are demanded to select and to choose which criminal cases are appropriate to be brought into court. The function of selecting criminal cases has helped the court in decreasing the number of cases handled, which has also contributed to increasing its efficiency.

Police investigators in Parepare Police Department, during their investigation, have considered which criminal cases are appropriate to be brought to the court. Police investigators tend to mediate criminal cases with 
minimal loss and those that could be resolved through deliberation. In this situation, police investigators used their discretion authority.

Mediation as a means to actualize restorative principles through discretion is implemented because the settlement between complainant and complainee has been achieved. It is common for the police investigators to found cases where the dispute of the involved parties has been settled, the losses have been paid, and the police report has been revoked. Although the police report has been revoked, reports that are not offense complaint can still be processed to the court by police investigators. However, for criminal cases with minimal losses and do not create public unrest, police investigators in Parepare Police Department have decided not to bring them to the court. The decision made by the police investigators shows the practice of discretion by which they uphold justice and expediency, despite forfeiting the legal certainty.

The practice of penal mediation by police investigators in Parepare Police Department in resolving certain criminal cases is based on the consideration of the impacts that might arise if the cases were to be resolved through legalistic formal. These impacts might include social conflict.

Police investigators in Parepare Police Department have realized that law is subject to change. The law is subject to changes resulted from dynamics occurred in society. If legal certainty is more emphasized, then justice and expediency will not be fulfilled. During their task, police investigators have tried to understand the needs of both parties involved in a criminal case in which police investigators forfeit legal certainty to fulfill their needs through a peaceful settlement.

Criminal case resolution made through a restorative justice approach is, essentially, focused on transforming the misconduct made by offenders with restoration efforts. Included in these efforts is restoring the relationship between both parties involved in the case.

The implementation of restorative justice through mediation as a criminal case resolution involves all involved parties. Those included are the offender and the victim, which together sought to solve the case and formulate the best possible solution that upholds their sense of justice. 
Restorative justice is a concept of thought and a response to the development of the Criminal Justice System that emphasize the need to involve society and the victim that tends to be forfeited in the current justice system.

Restorative justice can be implemented in resolving criminal cases through the acts of the police department that practiced mediation as a dispute resolution outside the court that focused on the best solution for both involved parties.

Dispute resolution by a mechanism outside the court through mediation has been commonly practiced and accepted by society. This acceptance is rooted in its capability to uphold their sense of justice. However, the practice of alternative dispute resolution has been heavily criticized by experts for a reason for its appropriate use in civil cases, not in criminal cases.

Criminal case resolution through mediation cannot be separated from the objectives of the law that are based on its philosophy (the law is justice) and the principles of dispute resolution process that are rooted in written and unwritten legal sources. Therefore, mediation practiced by the police department should refer to justice, legal certainty, and expediency values. Moreover, the implemented legal norms should put philosophical, juridical, and sociological foundations into consideration.

\section{CONCLUSION AND SUGGESTIONS}

A. Conclusion

1) The legal standing of penal mediation in the Indonesian' Criminal Justice System has not been recognized in resolving all criminal cases, for the exception of juvenile cases (Act No. 11/2012 on Criminal Justice System of Juvenile), domestic violence (Article 51-53 of Act No. 23/2004 on the Elimination of Domestic Violence), copyrights cases (Article 95, Paragraph (4) of Act No. 13/2016 on Copyrights). Criminal case resolution is based on the restorative justice approach as regulated in the Circular Letter of the National Police Chief No: SE/8/VII/2018 on the Implementation of Restorative Justice in Criminal Case Resolution.

2) Police investigators in Parepare Police Department have practiced penal mediation in resolving criminal cases based on the restorative justice as 
regulated in the Circular Letter of the National Police Chief No: SE/8/VII/2018 on the Implementation of Restorative Justice. Criminal case resolutions that have been done by Parepare Police Department through restorative approach in penal mediation is a correct and effective solution that reflects justice, prevents overcapacity in penitentiary institutions, prevents the increase of case arrears, and spending, and the unequal ratio between law enforcers and cases 
B. Suggestions

1) Penal mediation that has been commonly found is practiced through discretion. However, in future practices, regulation is needed to distinguish between cases that could be resolved through penal mediation, which is intended to prevent abuse of power from parties involved in the Criminal Justice System.

2) It is necessary to develop a shared perception between the criminal justice sub-system in enforcing restorative justice principles and mediation between disputed parties. A shared perception will further develop the implementation of restorative justice not only practiced in the investigation phase but also in the judiciary phase. 


\section{BIBLIOGRAPHY}

Adrianus Meliala, Penyelesaian Sengketa Alternatif: Posisi dan Potensinya di Indonesia, Makalah

Barda Nawawi Arief, 2008. Mediasi Penal Penyelesaian Perkara Diluar Pengadilan, Pustaka Magister, Semarang.

Puslitbang Hukum dan Peradilan Badan Litbang Diklat Kumdil Mahkamah Agung RI, 2011, Mediasi Penal Dalam Sistem Peradilan Pidana, Jakarta.

Satjipto Rahardjo.2007, Membangun Polisi sipil, Perspektif Hukum, Sosial, dan Kemasyarakatan, Jakarta: PT Kompas Media Nusantara.

Pasal 1 angka 1 dan Pasal 1 angka 4 Kitab Undang-undang Hukum Acara Pidana Indonesia

Surat Edaran Kapolri No : SE/8/VII/2018 tentang Penerapan Keadilan Restoratif (Restorative Justice) Dalam Penyelesaian Perkara Pidana.

Wawancara dengan Juman Simanjuntak, tanggal 6 Januari 2020 di Kantor Polresta Parepare

Data Kasus Pidana Polresta Parepare, tahun 2020.

https://www.hukumonline.com/berita/baca/lt5be1858164328/ini-kasus-kasuspidana-yang-bisa-dimediasi-di-indonesia/, diakses pada tanggal 23 November 2019, pukul 09.38 Wita. 